\title{
Contents List
}

ARTICLES page

Philippe VAN Parijs: The Second Marriage of Justice and Efficiency 1

David Clapham and Moira Munro: Ambiguities and Contradictions in the Provision of Sheltered Housing for Older People

Hartley DeAN and Peter Taylor-Gooby: Statutory Sick Pay and the Control of Sickness Absence

Jørn Henrik Petersen: The Danish 1891 Act on Old Age Relief: A Response to Agrarian Demand and Pressure

B. Hardy, G. Wistow and R. A. W. Rhodes: Policy Networks and the Implementation of Community Care Policy for People with Mental Handicaps

C. Pollitt, S. Harrison, D. J. Hunter and G. Marnoch: No Hiding Place: On the Discomforts of Researching the Contemporary Policy Process

Ewan Ferlie and Andrew Pettigrew: Coping with Change in the NHS: A Frontline District's Response To AIDS

URI YANAY: Service Delivery By a Trade Union - Does It Pay?

Alec Pemberton: Rescuing the Good Samaritan: An Exposition and a Defence of the Samaritan Principle in the Welfare State

BERRY MAYALL: The Division of Labour in Early Child Care - Mothers and Others

Tim Dant and Brian Gearing: Keyworkers for Elderly People in the Community: Case Managers and Care Co-ordinators

IAN SinclaIR, DAvid CRosbie and ANNE VICKERY: Organisational Influences on Professional Behaviour: Factors Affecting Social Work Involvement in 'Schemes'

RUTH LISTER: Women, Economic Dependency and Citizenship

CARoline Glendinning: Dependency and Interdependency: the Incomes of Informal Carers and the Impact of Social Security

JENNIE PoPAy and Gill JoNEs: Patterns of Health and Illness Amongst Lone Parents

ANDY FuRlong and GeORge COONEY: Getting on Their Bikes: Teenagers Leaving Home in Scotland in the 1980s

\section{COMMENT}

MARYSIA ZALEWSKI: Logical Contradictions in Feminist Health Care: A Rejoinder to Peggy Foster

DigBy ANDERSON: Good Samaritanism Versus Citizens' Welfare Rights. A Rejoinder to Alec Pemberton

\section{RESEARCH NOTE}

IAN Timaus: The Fall in the Number of Children in Care: A Demographic Analysis, 1977-1986 


\section{REVIEW ARTICLE}

James Mrdgley: Religion, Politics and Social Policy: The Case of the New Christian Right

\section{SOCIAL POLICY DIGEST}

Jo CAmpling

93, $245,405,557$

\section{BOOK REVIEWS}

P. SPICKER: Principles of Social Welfare - An Introduction to Thinking About the Welfare State (P. Taylor-Gooby)

T. Booth: Developing Policy Research (R. Walker)

R. DAvidson and P. WHITE: Information and Government Studies in the Dynamics of Policy Making (R. Walker)

S. BALDWIN, G. PARKER and R. WALKER (eds): Social Security and Community Care (A. S. Grealey)

J. Renshaw, R. Hampson, C. Thomason, R. Darton, K. Judge and M. KNAPP: Care in the Community: The First Steps (J. Twigg)

D. Hunter, N. MCKeganey and I. MacPherson: Care of the Elderly: Policy and Practice (J. Twigg)

G. WIKE: A Place Like Home: A Radical Experiment in Health Care (J. Twigg)

J. Neill, I. Sinclair, P. Gorbach and J. Williams: A Need for Care - Elderly Applicants for Local Authority Homes (A. Tinker)

I. Sinclair, D. Crosbie, P. O'ConNoR, L. STANFoRTH and A. VickERY: Bridging Two Worlds - Social Work and the Elderly Living Alone (A. Tinker)

R. BeRTHOUd and B. CASEY: The Cost of Care in Hostels (G. Fimister)

R. PARKER et al. : In Whose Trust? The Jasmine Beckford Inquiry and its Lessons for Foster Care (L. Harding)

R. Dingwall, A. M. Rafferty and C. WeBster: An Introduction to the Social History of Nursing (H. Jones)

C. HAM: Managing Health Services: Health Authority Members in Search of $A$ Role (J. P. Martin)

J. Solomos: Black Youth, Racism and the State. The Politics of Ideology and Reform (R. Behrens)

L. O. Williams: Partial Surrender. Race and Resistance in the Youth Service (R. Behrens)

B. Houlihan: Housing Policy and Central-Local Government Relations (P. Malpass)

M. BALL, M. HARLoE and M. Martens: Housing and Social Change in Europe and the USA (A. G. Champion)

I. LEVITT: Poverty and Welfare in Scotland 1890-1948 (D. Gladstone) 
A. GoRDON: The Crisis of Unemployment (N. Fraser)

A. CoRden: Disappointed Applicants. A Study of Unsuccessful Claims for Family Income Supplement (R. Berthoud)

S. HARRISON: Managing the National Health Service: Shifting the Frontier? (J. Higgins)

W. LAING, B. BRICKNELl, R. Forman and N. Saldana: Keeping the Lid On Costs? Essays on Private Health Insurance and Cost Containment in Britain (J. Higgins)

N. Manning: The Therapeutic Community Movement: Charisma and Routinization (D. Towell)

A. COYLE and J. SKINNER (eds): Women and Work: Positive Action for Change (C. Cousins)

P. KeMP (ed.): The Private Provision of Rented Housing (K. Kirby)

S. MAcGregor (ed.): Drugs and British Society: Responses to a Social Problem in the 1980s (G. Pearson)

P. WillmotT and A. Murie: Polarisation and Social Housing - the British and French Experience (J. Greve)

T. R. MARMOR and J. L. MASHAw (eds): Social Security: Beyond the Rhetoric of Crisis (R. Morris)

T. CAMPBELL: Justice (D. Miller)

K. Boh, M. BaK, C. Clason, M. Pankratova, J. Quortup, G. B. Sgritta and K. WaErness (eds): Changing Patterns of European Family Life: A Comparative Analysis of 14 European Countries (M. Henwood)

J. Dixon and R. P. Scheurell (eds): Social Welfare in Developed Market Countries (C. Jones)

H. PARKER: Instead of the Dole. An Enquiry into the Integration of the Tax and Benefit System (R. Berthoud)

B. JoRdan: The Common Good: Citizenship, Morality and Self-Interest (D. Watson)

E. Papadakis and P. Taylor-Gooby: The Private Provision of Public Welfare: State Market and Community (K. Judge)

B. Munday (ed.): The Crisis in Welfare: An International Perspective on Social Services and Social Work (J. Midgley)

N. Charles and M. KerR: Women, Food and Families (J. Popay)

G. WILson: Money in the Family: Financial Organisation and Women's Responsibility (G. Parker)

S. McRAE: Young and Jobless: The Social and Personal Consequences of Long-Term Unemployment (M. Maguire)

C. HASLUCK: Urban Unemployment: Local Labour Markets and Employment Initiatives (F. Robinson)

S. Box: Recession, Crime and Punishment (R. Reiner)

I. Crow, P. Richaroson, C. Riddington and F. Simon: Unemployment, Crime and Offenders (I. Strachan)

J. FORD: The Indebted Society: Credit and Default in the 1980s (M. Adler) 
F. Doling, J. Ford and B. StAfford (eds): The Property Owning Democracy (G. Parker)

R. MORRIS: Testing the Limits of Social Welfare (A. Gould) 575

P. Johnson, E. ConRAD and D. Thomson (eds): Workers Versus Pensioners: Intergenerational Justice in an Ageing World (S. Ward)

C. C. Havighurst, R. C. Helms, C. Bladen and M. V. Pauly: American Health Care. What are the Lessons for Britain? (J. Allsop)

A. WeALE (ed.): Cost and Choice in Health Care: the Ethical Dimension (J. Allsop)

M. Henkel, M. Kogan, T. Packwood and P. Youall: The Health Advisory Service: An Evaluation (R. Klein)

J. WeSTERGAARD, I. NOBLE and A. WALKER: After Redundancy: The Experience of Economic Insecurity (M. White)

H. Donnan and G. McFarlane (eds): Social Anthropology and Public Policy in Northern Ireland (R. Grillo)

S. SAINSBURY: Regulating Residential Care (M. Lomas)

H. JAсов: Silent Revolution. The Transformation of Divorce Law in the United States (J. Walker)

B. Holman: Putting Families First - Prevention and Child Care (J. Tunnard)

N. Frost and M. Stein: The Politics of Child Welfare: Inequality, Power and Change (N. Parton)

S. Sharkey and S. Barna: Community Care: People Leaving Long-Stay Hospitals (M. Bayley)

S. Williams and I. Aluen: Health Care for Single Homeless People (C. Stark) 


\section{Index of Authors}

Anderson, Digby, 553

Clapham, David, 27

Cooney, George, 535

Crosbie, David, 361

Dant, Tim, 331

Dean. Hartley, 47

Ferlie, Ewan, 191

Furlong, Andy, 535

Gearing, Brian, 331

Glendinning, Caroline, 469

Hardy, Brian, 141

Harrison, Stephen, 169

Hunter, David J., 169

Jones, Gill, 499

Lister, Ruth, 445

Marnoch, Gordon, 169

Mayall, Berry, 299

\section{Index of Reviewers}

Adler, Michael, 441

Allsop, Judith, 579

Bayley, Michael, 592

Behrens, Rob, 131

Berthoud, Richard, 139, 425

Champion, A. G., 134

Cousins, Christine, 267

Fimister, Geoff, 124

Fraser, Neil, 138

Gladstone, David, 136

Gould, Arthur, 575

Grealey, A. S., 117

Greve, John, 273

Grillo, Ralph, 584

Harding, Lorraine M., 126

Henwood, Melanie, 277

Higgins, Joan, 263

Jones, Catherine, 279

Jones, Helen, 128

Judge, Ken, 428

Kirby, Keith, 269

Klein, Rudolph, 581

Lomas, Malcolm, 586

Maguire, Malcolm, 435
Midgley, James, 397

Munro, Moira, 27

Pemberton, Alec, 281

Petersen, Jørn Henrik, 69

Pettigrew, Andrew, 191

Pollitt. Christopher, 169

Popay, Jennie, 499

Rhodes, R. A. W., 141

Sinclair, Ian, 361

Taylor-Gooby, Peter, 47

Timæus, Ian, 375

Van Parijs, Philippe, 1

Vickery, Anne, 361

Wistow, Gerald, 141

Yanay, Uri, 221

Zalewski, Marysia, 235
Malpass, Peter, 133

Martin. J. P., 129

Midgley, James, 430

Miller, David, 275

Morris, Robert, 274

Parker, Gillian, 433, 443

Parton, Nigel, 591

Pearson, Geoffrey, 271

Popay, Jennie, 431

Reiner, Robert, 437

Robinson, Fred, 436

Stark, Cathy, 594

Strachan, Ian, 440

Taylor-Gooby, Peter, 113

Tinker, Anthea, 122

Towell, David, 265

Tunnard, Jo, 589

Twigg, Julia, 119

Walker, Janet, 587

Walker, Robert, 114

Ward, Sue, 577

Watson, David, 427

White, Michael, 583 